\title{
ARTIGOS
}

\section{O CONCEITO DE GÊNERO MUSICAL NO REPERTÓRIO E NAS ÁREAS DE ANTROPOLOGIA, COMUNICAÇ̃̃O, ETNOMUSICOLOGIA E MUSICOLOGIA}

\author{
Marcio Guedes Correa \\ FIAM-FAAM Centro Universitário
}

\section{RESUMO}

Gêneros musicais são reconhecidos como nomenclaturas que servem para agrupar composições que conservam algum grau de similaridade entre si. Apesar de serem familiares para o público e para os profissionais de música, raramente se discute quais são as características necessárias para que uma determinada prática musical se concretize em um gênero, ou seja, o conceito de gênero em música raramente é submetido à análise. O objetivo desse artigo é trazer à baila algumas considerações a respeito das funções e utilizações dos gêneros musicais articuladas por diferentes autores das áreas de antropologia, comunicação, etnomusicologia e musicologia para, a partir delas, formular um possível conceito de gênero em música. As reflexões expostas e avaliadas nesse trabalho foram selecionadas por meio de uma pesquisa de caráter bibliográfico. Como resultado dessa análise, foi possível perceber que não há consenso a respeito do que é gênero musical. Dessa maneira, pode-se concluir que esse conceito se configura como um conjunto de funções e significados decorrentes de interesses diversos, atribuído às manifestações musicais.

Palavras-chave: Gênero musical. Manifestações musicais. Música erudita. Música popular. Música folclórica 


\section{Contextualização do termo "gênero musical"}

umerosas nomenclaturas são utilizadas para agrupar peças musicais que conservam alguma similaridade entre si. Tais nomenclaturas são amplamente utilizadas em diversos setores de nossa sociedade. No mercado musical, por exemplo, termos como samba, pagode, sertanejo, rock, pop, blues, sinfonia, concerto, entre outros, dão nome a grandes ajuntamentos de obras musicais semelhantes, perfazendo aquilo que comumente é entendido como gênero musical. Embora existam constantes e, até certo ponto, inevitáveis referências ao gênero em música, nem sempre há clareza sobre o significado deste termo. Afinal, o que é um gênero musical e quais são as características que levam determinadas práticas musicais a serem assim classificadas? Essa indagação me levou a buscar quais são as diferentes funções atribuídas aos gêneros e em que medida estudiosos de várias áreas do conhecimento o utilizam e atribuem a ele algum significado. Assim, busco determinar quais são os elementos musicais e extramusicais que contribuem para caracterizar certas práticas e manifestações como gêneros.

Para Gerard Denizeau (2005), gênero é o "objeto musical", ou seja, é o resultado dos elementos constituintes das composições e interpretações musicais que os diferenciam aos ouvidos do ouvinte. Para este pesquisador, o gênero não deve ser confundido com a forma musical, pois ela serve para estruturar e conferir coerência à composição, mas não é suficiente para designar o gênero. De fato, a forma sonata, a título de exemplo, é encontrada no gênero sonata, mas sua estrutura foi amplamente utilizada em outros gêneros musicais, tais como sinfonia, concerto e quarteto de cordas, e, em certa medida, inspirou práticas de exposição de temas entremeados por improvisações encontradas em gêneros como o jazz.

Outros autores, tais como Mário de Andrade (1989), Ulrich Michels (1999), Franco Fabbri (1981) e Joaquim Zamacois (1984), também afirmam que forma musical é um dos elementos que constituem um gênero, porém somente um conjunto de elementos musicais, históricos, políticos, sociais e mercadológicos, juntamente com a forma, pode caracterizá-lo. Sendo assim, entendo que forma e gênero são conceitos diferenciados.

Denizeau considera ainda que, quanto maiores as atribuições funcionais de um repertório, mais claros são seus gêneros. Isso significa que certas características de um gênero são conservadas para atender a demandas de públicos específicos, fato que, segundo esse autor, é facilmente observável no repertório do período Barroco, momento histórico em que muita música foi produzida para suprir necessidades de públicos claramente determinados, tais como nobreza, aristocracia, igreja etc. Ou seja, neste período, enquanto a ópera atendia às necessidades sociais, culturais e de entretenimento da aristocracia, o oratório servia às funções eclesiásticas. O minueto poderia ser utilizado para as danças dos salões nobres ou ser acoplado como movimento em peças musicais destinadas à apreciação, tais como concertos, suítes e partitas. Mú- 
sicas poderiam ser concebidas com finalidade didática, como aquelas que compõem o livro de Anna Magdalena Bach, obra engendrada por Johann S. Bach.

De modo análogo, pode-se observar que atualmente artistas de grande sucesso normalmente estão fortemente vinculados a algum gênero musical que, por sua vez, pode ter função de entretenimento, dança, apreciação etc. É impossível se referir a bandas como o Metallica e o Iron Maiden sem relacioná-las ao rock e seus derivados; do mesmo modo, associa-se Michael Jackson e Madonna ao pop; Gustavo Dudamel e Herbert Von Karajan aos gêneros da música erudita e assim por diante.

Bauman (2013) corrobora o pensamento de Denizeau quando manifesta que os elementos da cultura - e podemos entender que entre eles estão a música e as outras artes - foram utilizados durante muito tempo pelas elites como demarcadores dos espaços pertencentes a diferentes classes sociais que não estavam autorizadas a se amalgamar, ou seja, os repertórios musicais se referiam a públicos específicos e oriundos de camadas distintas de certas sociedades. Os gêneros musicais, portanto, poderiam ser vistos como marcas sonoras das práticas de diferentes classes sociais, ou seja, a eles era atribuída a função de distingui-las. Esse cenário, segundo Bauman, só passou a ser modificado a partir das novas propostas culturais dos filósofos do iluminismo, que pretendiam uma cultura refutadora do status quo que servisse de estímulo ao desenvolvimento de todo e qualquer ser humano, independentemente do pertencimento a esta ou àquela classe social. Ainda assim, pode-se perceber que alguns gêneros musicais ainda estão fortemente relacionados a determinadas camadas da sociedade. Nas primeiras décadas do século XX, o samba esteve ligado à população mais humilde do Brasil, aos habitantes das regiões mais carentes de nosso país. Hoje, o funk cumpre esse mesmo papel. O rock brasileiro da década de 1980 estava ligado à juventude, principalmente àquela residente nos subúrbios das grandes cidades. Os gêneros da música erudita, bem como as salas de concerto, ainda estão em grande medida relacionados a uma certa elite social.

Denizeau revela que, na música erudita do século $X X$, o conceito de gênero vai gradativamente perdendo sua utilidade. Isso ocorre pois os compositores deste período não mais escrevem para públicos determinados com tanta precisão. Não obstante, nesse mesmo século é possível perceber que classificações segundo os gêneros musicais ainda estão muito presentes no cenário da música popular de mercado. Este fato se deve à grande ligação que essa música ainda conserva com suas tradições.

A pesquisadora Elizabeth Travassos (2007), ao se debruçar sobre o conceito de música popular, esclarece que o termo surge para dar nome às músicas das manifestações mais populares que foram absorvidas pela indústria fonográfica e pelo rádio, sendo que aquelas que se mantiveram nas culturas populares são classificadas como "folclóricas" ou "de tradição oral"; portanto, o que se entende por música popular é o repertório trabalhado pelas rádios e gravadoras.

Janotti Júnior (2006) elucida que a constituição da música popular depende dos encontros entre a cultura popular e os dispositivos midiáticos. Consequentemente, 
os gêneros da música popular e da música de tradição oral são basicamente os mesmos, e seus compositores, diferentemente dos da música erudita do século XX, recorrem frequentemente aos gêneros como norteadores de suas criações musicais.

Além das abordagens musicais acadêmicas e de mercado que os gêneros recebem, autores oriundos de diversas áreas de conhecimento também se interessam por eles (CORREA, 2018). A seguir, descrevo como o conceito de gênero musical é contemplado e quais são suas funções em publicações científicas de duas áreas do conhecimento: a área de comunicação e a de antropologia.

\section{Gêneros musicais na área de comunicação}

Inspirados pelo conceito de "cultura popular massiva", cunhado pelo sociólogo jamaicano Stuart Hall, os autores dessa área de conhecimento criaram o termo "música popular massiva" para descrever um tipo de produção musical que recebe incisivas interferências do mercado com a intenção de alcançar o maior número possível de ouvintes consumidores. A categoria "música popular massiva" diferencia-se do conceito de música popular proposto por Elizabeth Travassos, descrito acima, não pelo propósito de vendagem, pois toda música profissionalizada busca alguma colocação comercial, mas pela decisiva interferência que as lógicas comerciais exercem sobre a criação artística. Muitos compositores e intérpretes da música popular dispõem de um considerável grau de criatividade, como é o caso de Tom Jobim, João Gilberto, Chico Buarque, Gilberto Gil, Caetano Veloso, João Bosco, Milton Santos, Hermeto Pascoal, Egberto Gismonti e tantos outros. Os artistas que atuam nos meios da música popular massiva, em sua maioria, precisam acatar regras claramente estabelecidas para facilitar os fluxos mercadológicos dos produtos musicais. É sobre essa produção que os autores da área de comunicação mais versam.

No ambiente da música popular massiva, os gêneros musicais são utilizados para promover a identificação dos públicos com os produtos que desejam consumir e, possivelmente, essa é sua principal função. Segundo Janotti Júnior (2003), o lançamento de um produto musical é sempre orientado por duas perguntas: Com o que se parece "esse som"? Quem irá comprar esse tipo de música? A primeira pergunta é respondida classificando o "som" segundo algum gênero musical. A resposta para a segunda pergunta depende da primeira, ou seja, o "tipo de música" em questão será vendido para consumidores contumazes do gênero musical identificado na resposta para a primeira indagação.

Embora sejam inegáveis a interferência da indústria fonográfica e dos ditames econômicos sobre as classificações musicais na música popular massiva, os gêneros musicais são também parte essencial dos julgamentos de valor que perpassam o consumo musical (JANOTTI JÚNIOR, 2003, p. 32). Isso significa que o público consumidor da música popular massiva não é parte totalmente passiva nesse meio. Seus anseios de consumo acabam por definir, de alguma maneira, aquilo que se espera ouvir em cada gênero musical, pois esses, além de guiarem as diferentes escutas e 
os diversos modos de consumo musical, acabam por fazer parte dos processos de identificação dos indivíduos.

Quantos de nós não se sentem completamente perdidos, para não dizer traídos, quando encontramos nossas lojas preferidas rearrumando o modo de catalogação dos discos? Se essa questão não envolvesse expressões identitárias e emocionais, seria muito mais fácil. Talvez os fãs de música passassem a adotar a ordem alfabética e não ficassem tanto tempo discutindo se a banda Led Zeppelin fica mais bem situada ao lado de roqueiros antigos, como Jimi Hendrix e Cream, ou na estante dedicada ao heavy metal. (JANOTTI JÚNIOR, 2003, p. 34).

A argumentação de Janotti Júnior a respeito das expressões identitárias é similar ao discurso de Bauman retratado no livro Identidade (2005). Para Bauman, foi somente no mundo contemporâneo globalizado que as identidades foram colocadas em discussão, pois, nesse ambiente, identidades, antes solidificadas por relações humanas regionalizadas, agora são liquefeitas pelo amplo diálogo estabelecido entre culturas anteriormente isoladas, ou pelo menos mais preservadas, proporcionado pelas novas relações econômicas, midiáticas e tecnológicas. Assim sendo, os indivíduos que vivem a globalização trocam uma identidade definida por um "processo de identificação". Se a identidade do indivíduo estava, anteriormente, sempre vinculada à comunidade à qual pertencia, no mundo globalizado ela está conectada, em grande medida, às "comunidades fundidas por ideias".

É porque existem tantas dessas ideias e princípios em torno dos quais se desenvolvem essas "comunidades de indivíduos que acreditam" que é preciso comparar, fazer escolhas, fazê-las repetidamente, reconsiderar escolhas já feitas em outras ocasiões, tentar conciliar demandas contraditórias e frequentemente incompatíveis. (BAUMAN, 2005, p. 17).

As reflexões de Bauman corroboram a impossibilidade, apontada por Janotti Júnior, de se catalogar música simplesmente por ordem alfabética. A classificação dos repertórios musicais em gêneros carrega complexas questões sociais e emocionais que nem mesmo as interferências econômicas e midiáticas do mundo contemporâneo globalizado conseguem diluir. É necessário considerar que, conforme elucidou Travassos, a música popular de rádio e da indústria fonográfica nada mais é do que um conjunto de gêneros da música de tradição oral que foi abarcado pelo mercado. Isto posto, é natural que as questões identitárias continuem presentes, de alguma forma, nas classificações segundo os gêneros realizadas pelas ferramentas midiáticas da música popular massiva, apesar de as relações do ser humano com a música terem sofrido severas modificações após o advento do rádio e da indústria fonográfica. Sendo assim, para os estudiosos da área de comunicação, os gêneros musicais cumprem também papel identitário. 
Janotti Júnior procura pôr em evidência a importância da performance na constituição e no reconhecimento de um gênero musical da música popular massiva. Uma canção, quando interpretada por outro artista que não o próprio compositor, pode assumir contornos divergentes da ideia original, conduzindo a composição a um gênero distinto daquele concebido pelo autor. Menciona-se o fato de que canções "bregas", regravadas por cantores consagrados da música popular brasileira, obtêm "ares refinados" (JANOTTI, 2004).

A título de exemplo, o autor recorda que a canção "Você não me ensinou a te esquecer", de Fernando Mendes, ${ }^{1}$ foi regravada por Caetano Veloso para a trilha musical do filme brasileiro Lisbela e o Prisioneiro ${ }^{2}$ e recebeu lugar de destaque na MPB, deixando de ser classificada como "música brega" (JANOTTI, 2004) e, por conseguinte, passou a ser vendida para um outro público e a fazer parte das questões identitárias desse novo grupo de pessoas.

Sendo assim, percebe-se que nos meios da música popular é costumeiro classificar seus artistas também de acordo com algum gênero musical, normalmente em conformidade com aquele da primeira canção de sucesso do artista em questão. Cantores e compositores como Raul Seixas e Rita Lee normalmente são relacionados ao gênero rock, embora outros gêneros estejam presentes em seus repertórios. Esse fato ocorre para facilitar que os públicos localizem não somente suas músicas favoritas, mas também os artistas que produzem aquilo que desejam consumir e que respondem, de alguma maneira, às suas questões de identidade.

Finalmente, é possível entender que o gênero na música popular massiva tem prioridade nas classificações e no reconhecimento das manifestações musicais. Para o ouvinte desse tipo de música, reconhecer o gênero é anterior ao reconhecimento do intérprete ou compositor. Ainda que ele, o ouvinte, não tenha consciência do que são gêneros musicais, seus hábitos de apreciação e consumo são guiados por eles, ou seja, há ouvintes que só gostam de rock, outros somente de samba e alguns, um pouco mais ecléticos, ouvem mais do que um único gênero musical; contudo, todos eles se fidelizam prioritariamente ao gênero.

\section{Gêneros musicais na área de antropologia}

Não são muitos os autores da antropologia que discutem os gêneros musicais (CORREA, 2018). Assim sendo, descreverei as abordagens de dois autores dessa área que atribuem especial importância a esse assunto e contribuem acentuadamente para a compreensão desse conceito.

Raquel Sant'Ana (2013) demonstra que alguns artistas podem criar novos gêne-

1 Cantor e compositor brasileiro frequentemente considerado "brega", nascido em 1950 e atuante até o presente momento. Alguns de seus discos gravados na década de 1970 chegaram a vender um milhão de cópias.

2 Longa-metragem brasileiro de 2003, dirigido por Miguel Arraes de Alencar Filho (Guel Arraes), frequentemente classificado como "comédia romântica". O filme é uma adaptação da peça teatral homônima de Osman Lins. 
ros, ainda que fortemente assemelhados a gêneros anteriores, e podem conceber novas formas de distribuição e divulgação de suas produções musicais como estratégia de reação aos artefatos midiáticos vigentes que cedem pouco ou nenhum espaço para a grande maioria dos artistas populares. Criar um novo nome para uma produção musical, idealizar um novo gênero, é uma tática para oferecer ao público um produto do qual a indústria fonográfica não dispõe. Esse fenômeno se fez possível em decorrência do surgimento de um amplo número de modernos equipamentos e softwares de gravação, mais ou menos acessíveis financeiramente, que permitiram a criação de estúdios caseiros com um grau considerável de qualidade. Assim, músicos puderam realizar seus trabalhos de gravação em casa, com baixo custo, e produzir cópias caseiras de CDs para vender diretamente ao público que frequenta suas apresentações. Essa prática é denominada por Sant'Ana como "autopirataria".

A "autopirataria", em alguns casos, conferiu independência aos artistas, que não precisavam mais estar vinculados a alguma gravadora, e, assim, os espaços de vendagem de fonogramas foram ampliados pela possibilidade de se copiar CDs em casa e pela distribuição e venda do fonograma digital no ambiente virtual da internet. O principal exemplo abordado pela autora foi o caso do gênero tecnobrega, surgido em Belém do Pará por volta do ano 2000 e que tem como principal expoente a cantora Gaby Amarantos e sua banda Tecnoshow.

A autora atribui importância ao tecnobrega, pois, segundo seu estudo, foi o primeiro gênero musical brasileiro a conquistar independência em relação às grandes gravadoras e serviu de modelo para novos mercados musicais. A partir desse momento, muitos outros artistas passaram a conquistar grandes espaços midiáticos independentes das grandes gravadoras e a atingir vultosos públicos em canais digitais da internet, como MySpace, YouTube, Facebook e, mais recentemente, Instagram, Deezer, Google Play e Spotify.

José Jorge de Carvalho (1999) discute o quanto as grandes gravadoras interferem nas sonoridades originais dos gêneros musicais nos estúdios de gravação e mixagem e como tais interferências podem transformar a sensibilidade musical contemporânea. Para Carvalho, os profissionais responsáveis pelas gravações e mixagens das grandes gravadoras aprendem um conjunto de técnicas e as utilizam uniformemente sobre todos os gêneros musicais. Essa prática foi amplamente difundida nos meios da música de mercado, e os gêneros musicais passaram a perder suas singularidades sonoras. Em outras palavras, um técnico de som usa as mesmas técnicas de estúdio para gravar e mixar gêneros distintos, como samba, sertanejo, baião, canção romântica etc. Os gêneros da música popular, principalmente os da música popular massiva, são equalizados quanto às suas sonoridades, resultando em menores possibilidades de estranheza pelos públicos que receberão esses produtos musicais.

Considero que não somente as técnicas de estúdio contribuem para um processo de igualização dos gêneros musicais, como também os conjuntos instrumentais e os tipos de vozes que são empregados. Formações como guitarra elétrica, contrabaixo elétrico, teclados eletrônicos/digitais e bateria são facilmente encontrados em grava- 
ções de diversos gêneros, homogeneizando sonoridades outrora muito distintas.

Destaco que, para Carvalho, há diferentes padrões estéticos que tornam possível a diferenciação entre gêneros musicais, mas essa noção vem sendo distorcida pela ação da música produzida pelo mercado de gravações, que busca, com o treinamento padronizado de seus técnicos, reduzir diferenças e causar o mínimo de estranheza ao seu público frente aos seus produtos. O autor discute especificidades anteriormente existentes em equalizações de gravações que valorizavam qualidades peculiares de gêneros musicais distintos e que, atualmente, vêm sendo substituídas por um padrão quase único de equalização, obscurecendo e nivelando atributos acústicos individuais. De acordo com essa abordagem, é preciso considerar que os ouvintes da música popular massiva estão envolvidos com a escuta de diferentes gêneros musicais que soam de forma muito assemelhada devido à interferência dos estúdios das grandes gravadoras. Então, os processos identitários dessa categoria de ouvinte estão relacionados não só às músicas, todas muito parecidas, mas também à imagem e aos padrões de comportamento expressados pelos artistas desse meio.

\section{Contribuições da musicologia e da etnomusicologia brasileiras para a compreensão do conceito de gênero musical}

Pesquisadores brasileiros relacionados às áreas de musicologia e etnomusicologia também vêm demonstrando algum interesse em discutir determinados gêneros musicais e em revelar suas características organizativas e funcionais. É notável que gêneros não são foco de estudos voltados à análise musical ou à musicologia histórica, porém eles se fazem presentes quando os fazeres musicais são determinantes para as relações sociais, para as construções culturais, para a educação, entre outros elementos.

Nessas áreas, entre outros assuntos, foram abordados gêneros que estão conectados com músicas que são compostas e tocadas por músicos que não possuem formação tradicional, que não sabem ler nem escrever partituras e que perpetuam seus conhecimentos musicais por estarem inseridos em alguma tradição musical ainda viva, como, por exemplo, os atuantes em rodas de choro, rodas de samba e os participantes de manifestações folclóricas. Para Ivaldo de Lara Filho, Gabriela Tunes da Silva e Ricardo Dourado Freire (2011), a performance tem primazia no entendimento dessas práticas musicais, já que é nela que os músicos envolvidos expressam os elementos estruturais das composições, que, em grande medida, são improvisadas. Os atributos de interpretação intrínsecos a cada um dos gêneros de música dessa categoria são classificados por Blacking como "ordem musical", conforme explicam Lara, Silva e Freire. Essa classificação dada por Blacking configura-se como um conjunto de maneirismos específicos presentes na interpretação, e, sem considerá-los, a caracterização do gênero fica prejudicada. 
Se pensarmos no choro, por exemplo, as melodias são frequentemente improvisadas. Isto só é possível para instrumentistas que estão familiarizados com esse gênero e, portanto, são capazes de conferir um sentido novo e particular para a mesma melodia em cada interpretação realizada. Dessa maneira, o choro depende da performance de cada instrumentista, e essa variedade de interpretações é que constitui a ordem musical do choro. Tal ordem não é discutida pelos músicos envolvidos, pois esses estão imbuídos dessa prática por fazerem parte do contexto cultural que gerou a música que interpretam. Complexos conhecimentos referentes à prática musical, tais como improvisação, ornamentação melódica, acompanhamento harmônico, contraponto, linhas de baixo, modulações e transposições, são transmitidos principalmente por meio da própria prática. Pouco se conceitua a respeito dessas habilidades.

Carlos Sandroni (2010) discutiu as questões sociorraciais que são intrínsecas a alguns gêneros da música popular abarcados pelos artefatos midiáticos da indústria fonográfica, principalmente o samba. Versa sobre a mestiçagem e o valor dessa em diferentes períodos da história do Brasil no século XX; esclarece que o consenso do samba ser o gênero musical que representa a cultura afro-brasileira não é estável, tampouco irrefutável. Além disso, Sandroni revela que entre 1930 e 1940, quando a palavra "negro" ou "negra" aparece no título ou na letra da canção, o gênero indicado na etiqueta do disco é "batuque" ou "macumba". Tais gêneros também são utilizados para catalogar canções que falam do sofrimento do povo negro outrora escravizado. "Jongo" é empregado quando surgem temas relacionados às religiões afro-brasileiras. Considera-se que o samba nasce da mescla entre os gêneros batuque, macumba, jongo, entre outros. Regina Meireles (2005) também se refere às mesclas de gêneros musicais que deram origem ao samba. A autora propõe uma discussão a respeito de gênero na medida em que busca delimitar as fronteiras entre o samba-canção e a modinha e entre o samba "batucado" e o maxixe. Para a autora, o ritmo tem papel fundamental para a diferenciação, que se deu no início do século XX, do gênero samba em relação ao maxixe. O ritmo mais "batucado" do samba o separaria definitivamente do maxixe (MEIRELLES, 2005, p. 53). Ao abordar os primórdios do samba-canção, a autora revela que houve uma fusão simplista da modinha e do samba. A canção se mantinha como modinha, e o acompanhamento rítmico era o samba, e essa mistura acabou por servir de classificação para diversas canções.

Também foram abordadas questões performáticas relacionadas aos gêneros musicais com foco na corporalidade do músico. Jorge Luiz Schroeder (2010) relata que uma elite cultural massificou os costumes performáticos, tanto na dança quanto na performance instrumental, e, de modo geral, dançarinos e músicos estão a serviço do seu corpo, ou seja, se esforçam para adaptar seus corpos aos padrões interpretativos vigentes. Este autor propõe que se olhe para a opção inversa na performance musical, ou seja, que a corporalidade natural dos músicos resulte em novos e singulares padrões interpretativos. Entendo que o conceito de corporalidade criado por esse autor refere-se à adaptação que certos músicos fazem das posturas 
e técnicas instrumentais para encontrar padrões interpretativos próprios. Por exemplo, o violonista Baden Powell, um dos focos de estudo de Schroeder, apesar de ter conhecido a escola clássica de violão, apoia o instrumento na perna direita cruzada sobre a esquerda, enquanto na postura clássica usa-se a perna esquerda como apoio, suspensa em um banquinho. A mão direita de Baden aplica mais força às cordas do que se espera em uma interpretação convencional, o que sugere que esse músico busca, de certa maneira, aproximar o ataque da sonoridade do violão ao dos instrumentos de percussão da música brasileira. Como exemplo, Schroeder reporta-se, além de Baden Powell, ao instrumentista e compositor Egberto Gismonti, ambos intérpretes que, apesar de terem passado por formação musical tradicional, são dotados de características performáticas bastante pessoais. Tais características presentes nesses dois músicos foram construídas com base em seus conhecimentos musicais fundamentados em gêneros oriundos tanto da música erudita quanto da música popular. Como resultado, os gêneros musicais tradicionais ganham roupagens inovadoras e arrojadas. Quando interpretados por eles, são amalgamados, flexibilizados, expandidos e, em alguns casos, chegam aos limites de cada gênero, tornando-os quase irreconhecíveis.

Schroeder afirma que a corporalidade musical de Baden Powell nasce do encontro entre a música erudita e a música popular, das influências de Tárrega, Fernando Sor e Andreas Segóvia, em contraponto com as de Dilermando Reis e Garoto. Identifica que há espaços no "bem tocar" de Baden, onde o "grotesco" se manifesta. Entendo que o termo "grotesco" é utilizado pelo autor para descrever os momentos da performance musical em que se renuncia ao refinamento técnico e à limpeza sonora para dar lugar aos padrões sonoros não previstos na tradição clássica europeia. Nesses momentos, pode-se prejudicar o cantabile de uma melodia para se evidenciar uma articulação não convencional ou acordes podem ser executados sem muita clareza em todas as suas notas para se preservar a precisão rítmica. Improvisações livres, que empregam sonoridades não diatônicas, também fazem parte dessa descrição proposta pelo autor. A relação entre o respeito à tradição musical e o "grotesco" presentes na performance de Baden traduz sua corporalidade, sua identidade no gênero música instrumental brasileira (SCHROEDER, 2010, p. 171).

Detendo-se em Egberto Gismonti, Schroeder analisa suas peculiaridades interpretativas exclusivamente no violão, já que Gismonti se define como um pianista que também toca violão. Para ele, a expressão violonística de Egberto Gismonti não faz referência aos padrões clássicos. Em vez disso, encontra sua força no inusitado. É justamente no "grotesco", no "borrão" e no "excesso" que Egberto constrói sua música para violão, o que o individualiza no gênero música instrumental brasileira (SCHROEDER, 2010, p. 175).

É importante destacar que até mesmo o violão utilizado por Egberto Gismonti não é convencional. Trata-se de um violão de dez cordas afinado de maneira alternativa. O ímpeto experimental do compositor o levou a desenvolver, em parceria com um luthier, um instrumento que possibilita a realização da sua música inovadora. 
É possível considerar que a análise de Schroeder propõe que a "música instrumental brasileira" seja vista como um novo gênero, identificado por mesclar outros gêneros brasileiros, permeando-os com complexas e elaboradas performances instrumentais que, em alguma medida, guardam relações com a estética da música erudita, mas que obrigatoriamente exploram padrões de interpretação altamente pessoais, individuais, condizentes com a "corporalidade musical" de cada artista. Em outras palavras, o gênero proposto por este autor nasce da hibridação de gêneros anteriores que são costurados por novos padrões de performance instrumental.

A hibridação entre gêneros musicais também está presente nas reflexões apresentadas por Beatriz Magalhães Castro e Pablo Garcia Costa (2009), autores que afirmam que as fusões entre os gêneros samba, choro e jazz na música de K-ximbinho fazem parte de um processo de modernização da música na globalização, oriunda da cultura de massa consumida e patrocinada por uma elite financeira que acreditava nos intercâmbios culturais entre o Brasil e os Estados Unidos da América.

Diante dessa estrutura, verifica-se na trajetória de K-ximbinho, assim como das orquestras Tabajara de Severino Araújo, e do Maestro Cipó, entre outros arranjadores e instrumentistas da época, um processo de adaptação e reorganização de saberes musicais para a formatação de um novo estilo musical, com elementos harmônicos do jazz e elementos rítmicos do choro, que permitisse aos músicos lugar de destaque no cenário musical. (CASTRO; COSTA, 2009, p. 124).

É notável que os autores acreditam que os saberes musicais passam pela necessidade de revisão e reestruturação e, em vista disso, surge também um novo tipo de músico capaz de ter fluidez no "novo estilo musical" nascido das conexões feitas entre a música brasileira e a norte-americana.

A improvisação musical como elemento determinante de certos gêneros musicais também é abordada na área de musicologia por César Albino e Sonia R. Albano de Lima (2011). Os autores afirmam que a improvisação sempre esteve presente no engendramento de práticas musicais que posteriormente se tornaram gêneros, mesmo que em algum momento ela passe a não fazer mais parte dos seus hábitos característicos. Advertem também sobre a dificuldade de contextualizar historicamente as práticas de improvisação devido à sua natureza não documental. $\mathrm{O}$ recorte da abordagem desses autores concentra-se sobre dois gêneros: o choro e o ragtime, ambos oriundos das Américas e que guardam características musicais comuns entre si.

O ragtime e o choro do início do século XX apresentam inúmeras semelhanças: ambos eram executados ao piano, muitas vezes pelos próprios compositores; havia a utilização efetiva das síncopes, muito comum na música africana, mescladas às características de danças oriundas da Europa, como é o caso da polca. (ALBINO; LIMA, 2011, p. 72). 
Quanto à improvisação no ragtime, os autores compreendem que é difícil determinar com precisão suas características musicais, pois o que ficou para a posteridade foram composições registradas em partituras, principalmente as de Scott Joplin. Da mesma maneira que se reconhece a capacidade de improvisação ao teclado de Johan Sebastian Bach apenas por relatos de época, sabe-se que o ragtime, em sua origem, nasceu da habilidade de improvisação ao piano de seus criadores.

No tocante ao choro, os autores entendem que sua origem se processou em conjuntos instrumentais compostos por escravos libertos e músicos advindos de bandas militares, como uma forma de imitação da polca, possivelmente bastante improvisado. Essa improvisação se limita a variações da melodia, logo, não há uma sessão predeterminada de improvisos no choro. Eles acontecem no decorrer da exposição das melodias em forma de pequenas alterações melódicas. Posteriormente o gênero é adaptado para o piano e seu maior expoente é Ernesto Nazareth, que preferia classificá-lo como tango brasileiro.

A questão do hibridismo entre gêneros musicais foi abordada também por Acácio Piedade (2011). Para ampliar a compreensão dos gêneros musicais, o autor faz uma reflexão sobre hibridismo, classificado em dois tipos: o homeostático e o contrastivo. No hibridismo homeostático, o corpo A se une ao corpo B e ambos se equilibram para resultar no corpo $C$, o híbrido. No caso do hibridismo contrastivo, os corpos $A$ e $B$ se unem em uma relação de imposição mútua. $O$ corpo $A$ se reafirma perante o $B$ e vice-versa, formando o corpo $A B$. Na visão de Piedade, o hibridismo em música é, na maioria dos casos, o do segundo tipo - o contrastivo. Antes de iniciar análises mais detalhadas a respeito dos gêneros musicais, o autor adverte que um gênero é constituído não apenas por sons, mas também por todos os fatos culturais que os permeiam e os constroem. É possível isolar os sons para empreender a análise puramente musical, mas, para compreender o todo, é preciso recompor a integridade do objeto (PIEDADE, 2011, p. 104). A síntese de fatos culturais que resulta em gêneros musicais tem, segundo essa análise, o poder de construir musicalidades, pois essas não estão nos indivíduos nem dependem de suas habilidades, mas se encontram na comunidade (PIEDADE, 2011, p. 105).

No meu entendimento, o autor revela que musicalidade depende da memória e que o esquecimento de antigas tensões entre gêneros musicais, resultado do hibridismo contrastivo, gera a estabilidade e a noção de gêneros ditos tradicionais. Sendo assim, o hibridismo homeostático nos gêneros musicais só é possível pois contrastes entre diferentes formas de se fazer música desapareceram com o tempo e se tornaram imemoráveis para a maioria das pessoas. Gêneros são o resultado de constantes e inevitáveis fusões de diferentes práticas musicais que, com o tempo, deixam de revelar conflitos internos e se estabilizam. Esses, por sua vez, se fundirão a outros gêneros, outras práticas musicais, e o ciclo que leva o hibridismo contrastivo ao hibridismo homeostático se reinicia. A título de exemplo, Piedade menciona que na obra de Johan Sebastian Bach há muitos elementos de música italiana que foram objetos de estudo frequentes realizados por esse compositor. No entanto, 
com o tempo, o eco da música italiana incorpora-se à musicalidade da obra de Bach e se torna perceptível apenas para os especialistas.

Piedade segue demonstrando em seu texto que diversos gêneros musicais aceitos como tradicionais, como, por exemplo, o baião, o choro e o samba, nasceram de fusões e de tensões contrastivas que outrora eram evidentes e que hoje foram esquecidas, gerando estabilidade aos gêneros musicais e possibilitando suas classificações.

\section{Considerações finais}

Apesar de haver constantes referências aos gêneros musicais nos meios de comunicação, na indústria fonográfica, nos canais digitais da internet e nas publicações científicas, ainda não é possível estabelecer o conceito de gênero musical de forma unívoca. O conceito vem sendo utilizado e adaptado para atender a diferentes demandas, sejam elas musicais, mercadológicas, sociais, antropológicas etc.

A área de comunicação é uma das que aborda os gêneros musicais com maior frequência, buscando, na maioria dos casos, analisar quais são seus empregos para as lógicas comerciais da música. Na música popular massiva, categoria bastante abordada nessa área, o gênero musical está aliado ao pensamento liberal utilitarista ${ }^{3}$ de John Stuart Mill e Jeremy Bentham, pois é uma ação que, ainda que com interesses meramente econômicos, procura trazer satisfação e alegria ao maior número possível de pessoas. Nesse ambiente, um artista permanece contratado por uma gravadora enquanto for útil, enquanto atingir ou superar as metas de vendas, enquanto seus discos e shows proporcionarem felicidade, mesmo que apenas no nível do entretenimento, para um público numerosamente e economicamente expressivo.

$\mathrm{Na}$ área de antropologia, é possível notar uma acentuada atenção da forma como o mercado interfere na constituição dos gêneros musicais, alterando suas estruturas originais e registrando-os em gravações homogeneizantes. Os efeitos dessa ação sobre a relação do ser humano com a música e as consequências para a sensibilidade musical dos indivíduos são pontos de grande interesse para os antropólogos. Por outro lado, verifica-se também a ação de artistas que buscaram se desvincular das grandes gravadoras para publicar seus trabalhos, encontrando modos alternativos para distribuir seus fonogramas, o que provocou alterações nas relações mercadológicas entre músicos, públicos e gravadoras.

Com respeito aos estudos da área de musicologia, é bom que se diga que seu campo foi ampliado para além da musicologia histórica e analítica, tomando para si questões pertinentes à cultura, ao indivíduo e sua corporalidade e, de certa maneira, fundindo-se à etnomusicologia.

3 O utilitarismo é uma doutrina ética e filosófica britânica dos séculos XVIII e XIX que afirma que uma ação é boa quando traz felicidade ao maior número possível de pessoas e má quando promove o efeito contrário. 
Os textos aqui avaliados foram coletados de revistas científicas de música, comunicação e antropologia, o que leva a crer que essas áreas têm buscado se inter-relacionar. Entre os autores da musicologia/etnomusicologia, naturalmente, percebe-se um relativo interesse para se compreender quais são as estruturas musicais que definem um gênero, embora não haja uma resposta unânime sobre a questão.

Finalizando minhas reflexões, considero que não há um consenso sobre o conceito de gênero em música. Ele pode ter funções e significados múltiplos, pois, se um gênero agrupa objetos ou espécies de acordo com suas similaridades, tal característica nem sempre é observável nas manifestações musicais. Dessa maneira, considero que ele se configura como um conjunto de funções e significados decorrentes de interesses diversos, atribuído às manifestações musicais.

\section{Referências}

ALBINO, Cesar; LIMA, Sonia R. Albano de. O percurso histórico da improvisação no ragtime e no choro. Per Musi, Belo Horizonte, n. 23, p. 71-81, 2011.

ANDRADE, Mário de. Dicionário Musical Brasileiro. São Paulo: Ed. USP, 1989.

BAUMAN, Zygmunt. Identidade: entrevista a Benedetto Vecchi. Trad. Carlos Alberto Medeiros. Rio de Janeiro: Zahar, 2005.

BAUMAN, Zygmunt. A cultura no mundo líquido moderno. Trad. Carlos Alberto Medeiros. 1. ed. Rio de Janeiro: Zahar, 2013.

CARVALHO, José Jorge de. Transformações da sensibilidade musical contemporânea. Horizontes Antropológicos, Porto Alegre, ano 5, n. 11, p. 53-91, out. 1999.

CASTRO, Beatriz Magalhães; COSTA, Pablo Garcia da. Elementos extramusicais na obra de K-ximbinho: questões sobre iconografia musical em suas capas de disco entre 1950 e 1960. Per Musi, Belo Horizonte, n. 23, p. 124-137, 2011.

CORREA, Marcio Guedes. Gêneros musicais e suas múltiplas funções e significados no repertório e nas diversas áreas de conhecimento. Tese (Doutorado) - Instituto de Artes, Unesp, São Paulo, 2018.

DENIZEAU, Gérard. Los géneros musicales: Una visión diferente de la historia de la música. Trad. Eva Jiménez Juliá. Barcelona: Ma non Troppo; Robinbook, 2005.

FABBRI, Franco. A theory of musical genres: two applications. In: INTERNATIONAL CONFERENCE ON POPULAR MUSIC STUDIES, 1., 1981, Amsterdam. Annals [...]. Amsterdam, 1981. 
JANOTTI JÚNIOR, Jeder Silveira. À procura da batida perfeita: A importância do gênero musical para a música popular massiva. Éco-pós, v. 6, n. 2, p. 31-46, ago./ dez. 2003.

JANOTTI JÚNIOR, Jeder Silveira. Gêneros musicais, performance, afeto e ritmo: uma proposta de análise midiática da música popular massiva. Contemporânea, v. 2, n. 2, p. 189-204, dez. 2004.

JANOTTI JÚNIOR, Jeder Silveira. Música popular massiva e gêneros musicais: produção e consumo da canção na mídia. Comunicação, Mídia e Consumo, São Paulo, v. 3 n. 7, p. 31-47, jul. 2006.

LARA Filho, Ivaldo Gadelha de; SILVA, Gabriela Tunes da; FREIRE, Ricardo Dourado. Análise do contexto da Roda de Choro com base no conceito de ordem musical de John Blacking. Per Musi, n. 23, jan./jul. 2011.

MEIRELLES, Regina. O samba-canção a eloquência de um gênero musical. Textos Escolhidos de Cultura e Arte Populares, v. 2, n. 2, 2005.

MICHELS, Ulrich (ed.). Atlas de música, I. Madrid: Alianza, 1999.

PIEDADE, Acácio. Perseguindo fios da meada: pensamentos sobre hibridismo, musicalidade e tópicas. Per Musi, Belo Horizonte, n. 23, p. 103-112, 2011.

SANDRONI, Carlos. Categorias raciais e gêneros musicais gravados no Rio de Janeiro dos anos 1930 e 1940. REVISTA USP, São Paulo, n. 87, p. 134-143, set./nov. 2010.

SANT'ANA, Raquel. Debates sobre o tecnobrega: indústria cultural em termos de pós-fordismo. Revista História e Cultura, Franca, v. 2, n. 2, p. 78-96, 2013.

SCHROEDER, Jorge Luiz. Corporalidade musical na música popular: uma visão da performance violonística de Baden Powell e Egberto Gismonti. Per Musi, Belo Horizonte, n. 22, 2010.

TRAVASSOS, Elizabeth. Tradição oral e história. Revista de História, Departamento de História da USP, São Paulo, n. 157, 2. sem. 2007.

ZAMACOIS, Joaquín. Temas de Estética y de Historia de la Música. Barcelona: Labor, 1984. 